\title{
anti-Carbobismuthination of Alkynes
}

Key words

bismuth

alkynes

carbobismuth-

ination

\section{SYNFACTting}

$\mathrm{R}^{1}=\mathrm{Ph}, 1,3-$ di- $-\mathrm{BuC} \mathrm{B}_{6} \mathrm{H}_{3}, 4-\mathrm{ClC}_{6} \mathrm{H}_{4}$, Hex $\mathrm{R}^{2} / \mathrm{R}^{3}=\mathrm{H}, \mathrm{Me}, \mathrm{Ph}$

electrophile $=\mathrm{I}_{2}$, TsCl, PhSSPh, RCOCl

Selected examples:

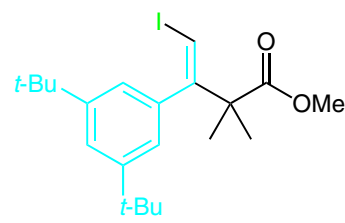

$99 \%$ yield

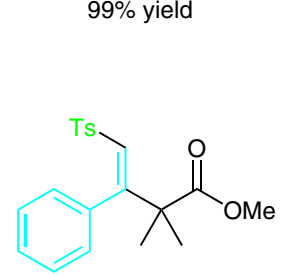

$60 \%$ yield

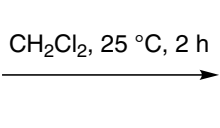

$\mathrm{R}^{1}$

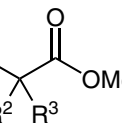

electrophile $\left(E^{+}\right)$

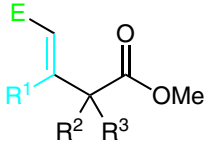

up to $99 \%$ yield<smiles>COC(=O)C(C)(C)C(=CI)c1ccc(Cl)cc1</smiles>

$77 \%$ yield

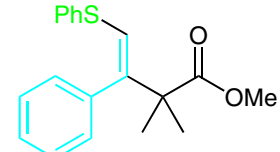

$66 \%$ yield<smiles>COC(=O)C(/C(=C/I)c1ccccc1)c1ccccc1</smiles>

$92 \%$ yield

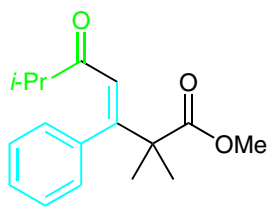

$84 \%$ yield
Significance: The first carbobismuthination of alkynes has been accomplished by the reaction of an alkyne, $\mathrm{BiBr}_{3}$, and a ketene silyl acetal to produce an alkenylbismuth compound with high stereo- and regioselectivity. $\mathrm{The}^{\mathrm{Br}}{ }_{2} \mathrm{Bi}$ group in the alkenylbismuth compounds can be substituted by I, Ts and SPh groups, and palladium-catalyzed cross-couplings with acid chlorides have been performed successfully.
Comment: The reaction of $\mathrm{BiBr}_{3}$ with a phenylacetylene derivative and a ketene silyl acetal gives monoalkenylbismuth dibromide as a white solid. X-ray crystallographic analysis of this product reveals that the carbobismuthination takes place regio- and stereoselectively in an anti-addition manner. 